\title{
REPRESENTASI PERSELINGKUHAN TOKOH DALAM KUMPULAN CERPEN SENJA DAN CINTA YANG BERDARAH KARYA SENO GUMIRA AJIDARMA
}

\author{
Ari Musdolifah \\ Pendidikan Bahasa dan Sastra Indonesia \\ Universitas Balikpapan \\ Jl. Pupuk Raya, Gn. Bahagia, Balikpapan, Kalimantan Timur \\ Email: ary.musdolifah@uniba-bpn.ac.id
}

\begin{abstract}
ABSTRAK
Penelitian tentang "Representasi Perselingkuhan Tokoh dalam Kumpulan Cerpen "Senja dan Cinta yang Berdarah" karya Seno Gumira Ajidarma" ini dilatarbelakangi pemikiran bahwa perselingkuhan merupakan fenomena kehidupan yang ditampilkan melalui karya sastra dengan menyisakan persoalan yang tiada akhir. Adapun tujuan penelitian ini adalah menjelaskan 1) alasan tokoh melakukan tindakan perselingkuhan, dan 2) cara tokoh terlibat konflik perselingkuhan. Kedua persoalan tersebut direduksi dari keseluruhan persoalan perselingkuhan dalam sepuluh cerpen yang dipilih. Pendekatan yang digunakan dalam penelitian ini adalah kualitatif. Adapun metode yang digunakan adalah deksriptif. Sementara itu, sumber datanya adalah sepuluh cerpen dalam kumpulan cerpen yang berjudul "Senja dan Cinta yang Berdarah" karya Seno Gumira Ajidarma. Wujud datanya adalah narasi, percakapan, atau dialog antara tokoh satu dengan tokoh yang lainnya dalam cerpen yang berkaitan dengan permasalahan penelitian. Pengumpulan data penelitian ini dilakukan menggunakan teknik tekstual (pustaka) dan teknik analisis data penelitian ini mengacu pada teknik analisis data menurut Miles dan Hubberman. Berdasarkan hasil penelitian dan pembahasan dapat disimpulkan bahwa 1) alasan-alasan tokoh melakukan perselingkuhan ini, yaitu keterpikatan fisik, kebutuhan biologis, kebutuhan komunikasi, kebutuhan akan kasih sayang, kebutuhan akan kebersamaan, dan tekanan. 2) Konflik yang terjadi oleh tokoh adalah konflik eksternal yang melibatkan percekcokan dan perkelahian, dan konflik internal yang melibatkan kebimbangan dari dalam diri tokoh.
\end{abstract}

Kata-Kata Kunci: Representasi, Perselingkuhan, Konflik, Cerpen.

\section{PENDAHULUAN}

Karya sastra merupakan cerminan, gambaran atau refleksi kehidupan yang terjadi di masyarakat ataupun kehidupan seseorang. Melalui karya sastra, pengarang mengungkapkan problematika kehidupan yang pengarang sendiri ikut berada di dalamnya. Karya sastra menerima pengaruh dari masyarakat dan sekaligus mampu memberi pengaruh terhadap masyarakat. Perhatian terhadap masyarakat justru meningkatkan pemahaman terhadap karya sastra sebab sebagai bagian integral. Masyarakat karya sastra pada dasarnya disusun berdasarkan atas model-model masyarakat (Ratna, 2010:306). Masyarakat yang dilukiskan adalah masyarakat dalam kehidupan sehari-hari sebagaimana dialami oleh pengarang. Perbedaannya adalah masyarakat tersebut telah bercampur dengan emosi, obsesi, cita-cita, dan citra pengarang. Menurut Plato (Faruk, 2010:47), dunia dalam karya sastra merupakan tiruan terhadap dunia kenyataan yang sebenarnya juga merupakan tiruan terhadap ide. 
Cerpen adalah salah satu bentuk karya sastra yang menyajikan cerita fiksi dalam bentuk tulisan. Cerpen mampu merefleksikan kehidupan masyarakat dari berbagi kurun waktu dan zaman. Cerpen Indonesia yang ditulis pada era moderen secara tidak langsung akan mencerminkan realitas sosial masyarakat pada masa itu. Sebuah cerpen menceritakan tentang kehidupan manusia dengan bermacammacam masalah dalam interaksi dengan lingkungan dan sesamanya. Seorang pengarang berusaha semaksimal mungkin mengarahkan pembaca kepada gambaran realita kehidupan melalui cerita yang ada dalam cerpen tersebut. Oleh sebab itu, pengarang mempunyai konsep yang berbeda-beda dalam melahirkan karyanya. Perbedaan konsep ini dapat disebakan oleh latar belakang pengarang pribadi dan kehidupan sosial kultural yang berbeda atau oleh adanya rasa individualis dan gejolak jiwanya. Hal ini menyebabkan tokoh yang ditampilkan dalam karya sastra merupakan tokoh yang memiliki jiwa dan gejolak dalam dirinya yang menyangkut masalah kehidupannya. Kehidupan yang dijalaninya akan membentuk jiwa tokoh menjadi kuat, menyesuaikan diri, atau mengantisipasi jalan hidupnya.

Kumpulan cerpen yang berjudul "Senja dan Cinta yang Berdarah", merupakan cerpen-cerpen yang dikumpulkan dari koran kompas dari tahun 1978-2013 yang ditulis oleh Seno Gumira Ajidarma dan disunting oleh Andina Dwifatma dalam penelitian ini. Kumpulan cerpen ini memiliki 42 cerita dari setiap periodenya. Masing-masing cerita memiliki tema tersendiri, seperti cinta, perselingkuhan, pembunuhan, penculikan, dan sebagainya menjadi konflik sosial dalam cerita tersebut. Realitas yang terdapat di masyarakat saat ini terefleksi melalui cerita dan karakter tokoh yang terdapat dalam kumpulan cerpen tersebut. Konflik-konflik yang terdapat dalam cerpen tersebut merupakan cermin dari masalah kehidupan yang terjadi di masyarakat.

Salah satu tema yang diangkat dalam penelitian ini adalah tema perselingkuhan. Dari 42 cerpen yang terdapat dalam kumpulan cerpen "Senja dan Cinta yang Berdarah" karya Seno Gumira Ajidarma ini, hanya sepuluh cerpen yang diteliti karena memiliki tema perselingkuhan. Cerpen-cerpen tersebut, yaitu "Suatu ketika dalam Kehidupan Dua Orang" (1978), "Ia dan Jendelanya" (1982), "Matinya Seorang Penari Telanjang” (1982), "Senja di Kuburan” (1983), "Suatu Ketika, Suatu Malam” (1983), "Penari dari Kutai” (1984), "Bibir yang Merah Basah dan Setengah Terbuka” (1988), "Petai” (1990), “Selamat Malam, Duhai Kekasih” (1997), dan “Cinta di atas Perahu Cadik” (2006).

Perselingkuhan adalah hubungan tidak resmi, tanpa melalui ikatan pernikahan antara seorang suami atau laki-laki dengan seorang wanita atau seorang istri atau wanita dengan seorang laki-laki di luar pasangan resmi yang berakibat cemburu dan ketidakharmonisan serta percekcokan atau perselisihan dalam rumah tangga (Saputra, 2013:1). Perselingkuhan yang dapat menyebabkan perceraian ataupun perdamaian kembali dengan pasangan, memiliki efek yang dapat mengganggu keamanan, pikiran dan harga diri semua anggota keluarga. 
Perselingkuhan merupakan topik yang menarik untuk dijadikan sebuah bentuk karya sastra. Salah satu contoh karya sastra yang mengangkat tema perselingkuhan adalah novel "Belenggu" karya Armijn Pane. Novel yang terbit pada tahun 1940 ini adalah novel yang bertemakan cinta segitiga, yang pada saat itu sudah umum di sastra Barat tetapi belum ada di sastra Indonesia. Novel ini tidak menunjukkan siapa yang baik, jahat, benar, atau salah, tetapi menggambarkan konflik batin sejenis manusia baru yang dibentuk karena persatuan budaya Timur dan Barat. Selain novel Belenggu, novel lain juga mengangkat tema perselingkuhan, seperti novel "Supernova" oleh Dewi Lestari.

Dipilihnya kesepuluh cerita pendek bertema perselingkuhan di atas pada penelitian ini, yaitu didasarkan pada beberapa alasan (1) dari banyaknya persoalan perselingkuhan yang terdapat pada kumpulan cerpen tersebut, maka hal ini menjadi persoalan yang penting untuk dikaji secara detail, (2) penelitian tentang konflik percintaan, khususnya perselingkuhan pada kumpulan cerpen "Senja dan Cinta yang Berdarah" karya Seno Gumira Ajidarma ini belum pernah diteliti oleh peneliti yang lain, (3) sepuluh cerpen yang dipilih dari 42 cerpen yang terdapat pada kumpulan cerpen "Senja dan Cinta yang Berdarah" karya Seno Gumira Ajidarma, yaitu "Suatu ketika dalam Kehidupan Dua Orang", "Ia dan Jendelanya", "Matinya Seorang Penari Telanjang", "Suatu Ketika, Suatu Malam", "Penari dari Kutai", "Bibir yang Merah Basah dan Setengah Terbuka", "Petai", "Selamat Malam, Duhai Kekasih", dan "Cinta di atas Perahu Cadik" ini adalah cerpen-cerpen yang khas membicarakan konflik perselingkuhan, (4) dalam kesepuluh cerpen yang telah dipilih dengan tema perselingkuhan tersebut memiliki gaya penceritaan yang unik karena pengarang merepresentasikan dengan apa adanya sesuai dengan cermin kenyataan di masyarakat, tidak ada yang harus ditutup-tutupi, dan tidak ada kemunafikan. Sehingga keadaan yang benar-benar apa adanya diceritakan secara terbuka dan logis karena cerita tersebut dapat membuat pembaca berpikir untuk merefleksi kesah cerpen tersebut dengan kenyataan di dunia nyata, (5) permasalahan perselingkuhan yang diangkat pada penelitian ini didasarkan karena keterbiasaan masyarakat dengan perselingkuhan yang disuguhkan oleh berbagai macam media sosial. Oleh sebab itu, masyarakat menjadi terbiasa mendengar dan tidak terkejut lagi. Hal itulah yang akan dikaji lebih mendalam untuk mendapatkan konsepsi dari perselingkuhan didasarkan pada alasan tokoh melakukan perselingkuhan dan cara tokoh terlibat konflik perselingkuhan.

Aspek-aspek yang terdapat dalam perselingkuhan meliputi, pengertian perselingkuhan, bentukbentuk perselingkuhan, faktor penyebab perselingkuhan, hal-hal yang menarik untuk melakukan perselingkuhan, faktor yang mendorong perselingkuhan, hal-hal yang terjadi ketika pasangan jatuh cinta dengan orang lain (Subotnik \& Harris dalam Ginanjar, 2009:65). Pada penelitian ini aspek-aspek 
perselingkuhan hanya dibatasi dengan pengertian perselingkuhan, alasan perselingkuhan, dan bentukbentuk perselingkuhan yang sesuai dengan permasalahan penelitian.

Fokus penelitian ini adalah perselingkuhan tokoh yang terjadi pada rumah tangga dari sepuluh cerpen dipilih pada kumpulan cerpen "Senja dan Cinta yang Berdarah" karya Seno Gumira Ajidarma. Penelitian ini menggunakan teori representasi oleh Stuart Hall. Selanjutnya dikupas secara lebih dalam lagi mengenai alasan tokoh melakukan perselingkuhan, cara tokoh terlibat konflik perselingkuhan. Menurut Stuart Hall (1997:15), representasi adalah penggunaan bahasa untuk mengatakan sesuatu atau untuk merepresentasikan sesuatu yang bermakna terhadap orang lain. Dari pandangannya, ia menganggap representasi merupakan bagian yang paling penting sebagai proses saat makna diproduksi dan kemudian digunakan antarmasyarakat di dalam lingkup budaya.

Kumpulan cerpen yang berjudul "Senja dan Cinta yang Berdarah" karya Seno Gumira Ajidarma ini memiliki persoalan penting dalam kehidupan bermasyarakat, yaitu mengenai perselingkuhan. Hingga saat ini, penelitian dengan tema perselingkuhan yang terdapat pada kumpulan cerpen tersebut belum pernah ada yang menelitinya. Berdasarkan hal tersebut dilakukan sebuah penelitian yang berjudul "Representasi Perselingkuhan Tokoh dalam Kumpulan Cerpen"Senja dan Cinta yang Berdarah" Karya Seno Gumira Ajidarma" untuk diteliti secara mendalam. Dengan demikian, tujuan dari penelitian ini, yaitu (1) mendeskripsikan tokoh melakukan tindakan perselingkuhan, (2) mendeskripsikan cara tokoh terlibat konflik perselingkuhan.

\section{METODE}

Pendekatan yang digunakan pada penelitian ini adalah pendekatan kualitatif. pendekatan kualitatif adalah suatu pendekatan yang meneliti gejala sosial dengan deskripsi dalam bentuk kata-kata dalam bahasa. Dalam penelitian ini data yang ditemukan dalam sepuluh cerpen dari kumpulan cerpen "Senja dan Cinta yang Berdarah" karya Seno Gumira Ajidarma dideskripsikan dalam bentuk kalimat, agar dapat diinterpretasikan untuk mendapat jawaban dari masalah yang telah dirumuskan dengan cara menelaah dan menganalisis data dengan berbagai referensi yang relevan.

Data penelitian ini berupa percakapan atau dialog, dan narasi yang terdapat pada sepuluh cerpen yang dipilih dari kumpulan cerpen "Senja dan Cinta yang Berdarah" karya Seno Gumira Ajidarma yang terkait dengan permasalahan penelitian tentang representasi perselingkuhan. Objek data dalam penelitian adalah fakta-fakta sosial pada teks cerpen yang merupakan cermin dari realita masyarakat yang terkait dengan perselingkuhan.

Sumber data penelitian ini adalah kumpulan cerpen "Senja dan Cinta yang Berdarah" karya Seno Gumira Ajidarma yang merupakan kumpulan cerpen pertama yang diterbitkan pada bulan Juni 
2014. Kumpulan cerpen ini diterbitkan oleh Penerbit Buku Kompas, tebal buku 822 halaman dan sampul berwarna orange bergambar wajah wanita dengan rambut terurai.

Teknik analisis data penelitian ini mengacu pada teknik analisis data menurut Miles dan Hubberman. Menurut Miles dan Hubberman (diterjemahkan oleh Rohidi, 2014:16-20), aktivitas dalam analisis data, yaitu reduksi data, penyajian data, dan kesimpulan/verifikasi. Pada langkah reduksi data, data-data yang dipilih berupa kalimat, percakapan, atau dialog, dan narasi dianalisis untuk diperoleh makna melalui pendekatan konstruksionis oleh Stuart Hall yang terkait dengan masalah yang diteliti, yaitu alasan tokoh melakukan perlingkuhan dan cara tokoh terlibat perselingkuhan. Informasiinformasi yang mengacu pada permasalahan itulah yang menjadi data dalam penelitian ini. Pada langkah penyajian data, data-data yang berupa kalimat, percakapan, atau dialog, dan narasi tersebut ditafsirkan. Langkah ketiga adalah penarikan kesimpulan dan verifikasi.

\section{HASIL DAN PEMBAHASAN}

1. Cerpen

Cerpen merupakan prosa fiksi dan proses fiksi tidak dapat terlepas dari unsur-unsur pembangun cerita. Unsur-unsur yang membangun karya sastra itu sendiri disebut unsur instrinsik (Nurgiyantoro, 1995:23). Unsur-unsur inilah yang menyebabkan karya sastra hadir sebagai karya sastra, yaitu unsurunsur yang secara faktual akan dijumpai jika orang membaca karya sastra. Unsur intrinsik sebuah cerpen adalah unsur-unsur yang (secara langsung) turut serta membangun cerita. Begitu pun sebaliknya, jika dilihat dari sudut pembaca, maka unsur-unsur (cerita) inilah yang akan dijumpai jika membaca sebuah cerpen. Secara umum unsur-unsur yang dimaksud, yaitu alur, plot, penokohan, tema, lattar, dan sudut pandang.

\section{Representasi}

Penelitian ini menggunakan teori representasi yang dikemukan oleh Hall dalam bukunya yang berjudul Representation: Cultural Representation and Signifying Practices (1997). Dikatakan bahwa representasi tidak dapat terlepas dari sebuah kebudayaan yang terdapat di masyarakat. Menurut Hall (1997:15), representasi adalah penggunaan bahasa untuk menyatakan sesuatu yang memiliki arti atau merepresentasikan dunia ini dengan penuh makna. Selain itu, representasi juga merupakan sebuah bagian penting dari proses. Melalui proses itu, makna tersebut diproduksi dan dipertukarkan antar orang-orang yang ada di lingkup kebudayaan yang sama. Di dalamnya juga terdapat penggunaan bahasa, tanda dan gambaran makna yang merepresentasikan sesuatu.

Tiga pendekatan dalam representasi, yaitu Reflective Approache (pendekatan reflektif), Intentional Approache (pendekatan intensional), dan Constructionist Approach (pendekatan 
kontruksionis). Ketiga pendekatan tersebut dapat menjelaskan bagaimana sebuah representasi dimaknai melalui cara kerja bahasa yang digunakan (Hall, 1997:24-25). Berikut penjelasan dari ketiganya.

a. Reflective Approache, merupakan sebuah pikiran yang terletak pada objek, ide, peristiwa yang ada di dunia nyata karena bahasa seperti cermin yang memiliki kegunaan untuk merefleksikan makna. Tanda-tanda visual benar-benar menunjang hubungan tertentu antara bentuk dan struktur objek yang mereka gambarkan.

b. Intentional Approache, menganggap bahwa penulis yang menentukan arti atau makna uniknya pada bahasa. Bahasa digunakan untuk menyampaikan atau mengkomunikasikan segala sesuatu yang khusus atau unik pada kita. Namun, kita tidak bisa menjadi sumber arti atau makna yang tunggal dalam bahasa karena itu akan berarti bahwa kita bisa mengungkapkan diri kita sendiri seluruhnya dalam bahasa pribadi. Tetapi, esensi bahasa adalah komunikasi dan itu secara bergiliran bergantung pada kaidah linguistik yang sama-sama digunakan.

c. Construction Approach, pendekatan ini berhubungan dengan bahasa sosial. Dunia ini penuh dengan alam, benda, kejadian, manusia, dan lain-lain. Oleh karena itu, semua hal yang ada di dalamnya dikelola dengan makna, representasi, dan bahasa. Bukan dunia ini yang memberikan makna, melainkan makhluk sosial yang membangun arti atau makna itu dalam sebuah bahasa. Kemudian, makna ini digunakan untuk merepresentasikan sesuatu dalam kehidupan manusia.

Berdasarkan penjelasan di atas dapat diperoleh pemahaman bahwa representasi adalah suatu proses untuk memproduksi makna dari konsep yang ada dipikiran melalui bahasa. Proses produksi makna tersebut dimungkinkan dengan hadirnya sistem representasi. Namun, proses pemaknaan tersebut tergantung pada latar belakang pengetahuan dan pemahaman suatu kelompok sosial terhadap suatu tanda. Suatu kelompok harus memiliki pengalaman yang sama untuk dapat memaknai sesuatu dengan cara yang nyaris sama.

\section{Psikologi Karya Sastra}

Psikologi adalah ilmu yang mempelajari aspek kejiwaan manusia. Jiwa adalah sesuatu yang abstrak, hanya dapat diteliti melalui faktor yang membentuknya dan hasil yang ditimbulkannya. Dengan begitu, saat meneliti aspek kejiwaan seseorang, kita tidak boleh hanya melihat dari satu aspek saja. Misalnya, kita tidak bisa meneliti kejiwaan seseorang dari tingkah lakunya saja. Kita harus memperhatikan faktor penampilan, lingkungan, usia, dan lain sebagainya. Psikologi juga dapat diterapkan pada karya sastra untuk menganalisis kejiwaan para tokoh. Kedua ilmu tersebut disatukan sehingga muncul istilah psikologi sastra. Psikologi sastra mengenal karya sastra sebagai pantulan kejiwaan. Pengarang menangkap gejala kejiwaan lalu mengolahnya ke dalam teks dan dilengkapi dengan kejiwaanya. Menurut Minderop (2011:54), psikologi sastra adalah telaah karya sastra yang 
diyakini mencerminkan proses dan aktivitas kejiwaan. Sementara menurut Ratna (2004:350), psikologi sastra adalah analisis teks dengan mempertimbangkan relevansi dan peranan studi psikologis.

Berdasarkan pengertian dari beberapa ahli di atas dapat diperoleh pemahaman bahwa psikologi sastra adalah telaah karya sastra yang mencerminkan proses dan aktivitas kejiwaan yang dianalisis dengan mempetimbangkan relevansi dan peranan studi psikologis. Oleh sebab itu, berbagai macam tingkah laku yang dicerminkan tokoh dalam teks sastra dapat dikaitkan dengan teori-teori psikologi yang relevan untuk dianalisis.

4. Perselingkuhan dalam Karya Sastra

Perselingkuhan perlu diwaspadai, karena perselingkuhan dapat terjadi di mana pun dan kapan pun. Jannah (2007:43) perselingkuhan adalah sebuah pengkhianatan terhadap istri atau suami karena tindakan ini melanggar harapan dan komitmen yang sah. Menurut Shaby (2011:10), selingkuh berarti hubungan romantis dengan yang bukan pasangan atau pacar resmi atau melakukan sesuatu tidak dalam koridor komitmen. Sementara menurut Blow dan Harnett (Asriana \& Ratnasari, 2012:84), perselingkuhan adalah kegiatan seksual dan atau emosional yang dilakukan oleh salah satu atau kedua individu yang terikat dalam hubungan berkomitmen dan dianggap melanggar kepercayaan dan atau norma-norma (yang terlihat maupun tidak terlihat) yang berhubungan dengan eksklusivitas emosional atau seksual. Sedangkan menurut Wattimena (2010:11), kata affair (perselingkuhan) dalam bahasa Inggris memiliki beragam arti, yaitu urusan, sesuatu yang harus dilakukan, skandal, kontroversi, atau relasi seksual antara dua orang yang mengkhianati pasangannya masing-masing. Sementara menurut Saputra (2013:1), perselingkuhan adalah hubungan tidak resmi, tanpa melalui ikatan pernikahan antara seorang suami atau laki-laki dengan seorang wanita atau seorang istri atau wanita dengan seorang lakilaki di luar pasangan resmi yang berakibat menimbulkan cemburu dan ketidakharmonisan serta percekcokan atau perselisihan dalam rumah tangga.

Berdasarkan beberapa pengertian di atas dapat diperoleh pemahaman bahwa perselingkuhan adalah suatu bentuk pengkhianatan berupa hubungan romantis terhadap istri atau suami yang dianggap melanggar komitmen yang sah dengan ekslusivitas emosional atau seksual yang dapat menimbulkan cemburu dan ketidakharmonisan serta percekcokan atau perselisihan dalam rumah tangga. Kecemburuan yang terjadi dapat berupa kemarahan dan kekesalan dari pasangan yang menjadi korban perselingkuhan. Sementara itu, keharmonisan yang mendasari keutuhan dalam rumah tangga adalah saling sayang menyayangi dan perhatian antara suami dan istri. Selingkuh adalah bentuk praktik kehidupan yang tidak terpuji. Jika disorot dari sudut pandang hukum, kesehatan, sosial, budaya, bahkan agama, perselingkuhan selalu penuh dan sarat dengan kebohongan. Bohong pada diri sendiri, istri, suami, anak-anak, lingkungan dan masyarakat, bahkan Tuhan (Shaby, 2011:13). 


\section{Bentuk-Bentuk Perselingkuhan}

Perselingkuhan dapat dibagi menjadi beberapa bentuk. Penggolongannya didasarkan derajat keterlibatan emosional dari pasangan yang berselingkuh. Menurut Subotnik dan Harris (Wisnuwardhani \& Mashoedi, 2012:109-110), bentuk-bentuk perselingkuhan tersebut dapat diuraikan sebagai berikut.

\section{a. Serial Affair}

Tipe perselingkuhan ini paling sedikit melibatkan keintiman emosional, tetapi terjadi berkalikali. Hubungan yang terbentuk dapat berupa perselingkuhan semalam atau sejumlah affair yang berlangsung cukup lama. Dalam serial affair tidak terdapat keterlibatan emosional, hubungan yang dijalin hanya untuk memperoleh kenikmatan atau petualan sesaat. Inti dari perselingkuhan ini adalah untuk seks dan kegairahan.

\section{b. Flings Affair}

Tipe perselingkuhan ini mirip dengan serial affair, juga ditandai oleh minimnya keterlibatan emosional. Perselingkuhan tipe ini belum menunjukkan adanya keterikatan emosional dan komitmen apapun terhadap pasangan selingkuhannya. Perselingkuhan ini dapat terjadi karena adanya suasana serta kondisi yang mendukung dan memungkinkan terjadinya perselingkuhan, misalnya daya tarik sesaat antara pria dan wanita yang kebetulan berada jauh dari pasangan hidupnya. Hubungan yang terjadi dapat berupa perselingkuhan satu malam atau hubungan yang terjadi selama beberapa bulan, tetapi hanya terjadi satu kali saja. Dibandingkan dengan tipe perselingkuhan yang lain, flings affair termasuk yang paling tidak serius dampaknya.

\section{c. Romantic Love Affair}

Perselingkuhan tipe ini melibatkan hubungan emosional yang mendalam. Pihak yang berselingkuh merasa jatuh cinta lagi dan menemukan hubungan yang lebih memuaskan dengan pasangan selingkuh secara fisik dan emosional. Hubungan yang terjalin menjadi amat penting dalam keseluruhan kehidupan pasangan. Seringkali pasangan berpikir untuk melepaskan perkawinan dan menikahi kekasihnya. Bila perceraian tidak memungkinkan, perselingkuhan tersebut dapat berlangsung jangka panjang.

\section{d. Long Term Affair}

Perselingkuhan jangka panjang merupakan hubungan yang menyangkut keterlibatan emosional paling mendalam. Hubungan dapat berlangsung bertahun-tahun dan bahkan sepanjang kehidupan perkawinan. Cukup banyak pasangan yang merasa memiliki hubungan lebih baik dengan pasangan selingkuhnya daripada dengan suami atau istri. Karena perselingkuhan sudah berlangsung lama, tidak jarang hubungan ini juga diketahui oleh istri dan bahkan pihak keluarga. Pada sejumlah pasangan 
tertentu, seolah ada perjanjian tidak tertulis bahwa perselingkuhan, boleh terus berjalan asalkan suami tetap memberikan kehidupan yang layak bagi istri dan anak-anak.

\section{Alasan Perselingkuhan Tokoh dalam Kumpulan Cerpen "Senja dan Cinta yang Berdarah" karya Seno Gumira Ajidarma}

\section{a. Keterpikatan Fisik Tokoh dalam Kumpulan Cerpen "Senja dan Cinta yang Berdarah" Karya Seno Gumira Ajidarma \\ 1) Cerpen "Selamat Malam, Duhai Kekasih"}

Tokoh Sukab tertarik dengan tokoh Tumirah pada saat tokoh Tumirah sedang menari. Tokoh Tumirah yang selalu mengenakan kain dan kebaya merah, dengan rambut terurai dan sandal jepit juga merah membuat tokoh Sukab tergila-gila. Tokoh Sukab terus membayangkan tokoh Tumirah hingga di rumah. Pada saat bersama tokoh istri pun, ia masih saja membayangkan tokoh Tumirah, sehingga tokoh istri pun mengetahuinya.

Langkahnya menjadi ringan, seringan hatinya yang sejak sore sudah melayangmelayang. Tumirah, ya Tumirah, perempuan itu sudah berjanji akan menunggunya di malam Tahun Baru. Sudah berjanji akan berjoget di lapangan sepakbola di kampungnya yang kini menjadi arena pesta. Tumirah, Tumirah, telah dibayangkannya perempuan bertubuh sintal itu, dengan kain dan kebaya merah, dengan rambut terurai sampai ke bahu, dengan sandal jepit merek swallow, bergoyang dan bergoyang di arena jojing yang becek tapi membakar (SDCYB/2014:584).

Keterpikatan fisik tokoh Sukab terhadap tokoh Tumirah terlihat dari kutipan di atas. Tokoh Sukab terpikat pada tokoh Tumirah karena tubuhnya sintal, rambut terurai sampai ke bahu, dan pintar bergoyang (menari). Tokoh Tumirah memang primadona di arena dangdut. Setiap gerakannya penuh dengan pesona. Tokoh Sukab menyukai dangdut, hingga akhirnya ia tergoda dengan tokoh Tumirah.

\section{b. Kebutuhan Biologis Tokoh dalam Kumpulan Cerpen "Senja dan Cinta yang Berdarah" Karya Seno Gumira Ajidarma}

1) Cerpen "Ia dan Jendelanya"

Cerpen ini diawali dengan tokoh Ia yang sedang memandang keluar jendela apartemennya. Ia melihat banyak aktifitas manusia yang dilakukan pada malam itu. Kegiatan ini merupakan rutinitasnya sehari-hari selain merenung. Tidak berapa lama tokoh lelaki datang mengetuk pintu apartemennya, masuk, dan memutar musik. Tokoh Ia pun segera mandi dan begitu selesai mandi ia mendatangi tokoh lelaki tersebut sambil berkaca dan memandang tubuhnya sendiri.

"Setidaknya jika lelaki hanya butuh tubuh saja dari seorang perempuan," sambungnya.

"Tapi aku bukan lelaki seperti itu."

Perempuan itu pun mendekat, dan berbisik ditelinganya. 
"Apakah itu penting, darling? Aku bisa dan mau tidur dengan siapa saja. Dalam keremangan, tanpa diketahui seorang pun, wajah lelaki itu menjadi merah. Tak jelas, karena minuman ataukah ucapan perempuan itu.

Di luar, malam sudah lengkap. Di celah daunan palem itu terlihat bulan perak sebesar piring. Lampu jalanan yang cahayanya membias di udara, dan selorot lampu mobil atau motor yang silih berganti di tikungan.

Dua manusia dalam ruangan itu tidak saling bercakap lagi. Lagu dari kaset telah habis dari tadi. Dari luar, tak tampak ada usaha untuk membaliknya, atau mengganti dengan kaset yang lain (SDCYB/2014:78-79).

Kutipan di atas menunjukkan bahwa tokoh Ia memperlihatkan tubuhnya yang telanjang kepada tokoh lelaki. Setelah itu Ia berkaca dan mengungkapkan bahwa badannya masih indah untuk lelaki yang hanya mencarinya untuk tubuhnya saja. Tokoh lelaki itu membantahnya dengan mengatakan bahwa Ia bukan lelaki yang seperti itu. Sanggahan itu pun dibantah juga oleh tokoh Ia, bahwa sanggahan dari tokoh lelaki itu tidak penting, dan Ia bisa melakukannya dengan pria manapun tanpa seorang pun mengetahuinya. Sanggahan yang diberikan oleh tokoh Ia itu membuat merah wajah tokoh lelaki, tetapi tidak jelas apakah karena sanggahan dari tokoh Ia tersebut atau karena minumannya. Setelah itu tidak ada pembicaraan lagi dan merekapun melakukan hubungan seksual. Hal ini dibuktikan dengan musik yang telah habis dan tidak ada usaha dari mereka untuk memutarnya lagi.

\section{c. Kebutuhan Komunikasi Tokoh dalam Kumpulan Cerpen "Senja dan Cinta yang Berdarah" Karya Seno Gumira Ajidarma \\ 1) Petai}

Cerita ini diawali dengan pembicaraan antara tokoh lelaki dan tokoh wanita tentang petai. Mereka memang baru saja makan malam dengan lauk petai. Tokoh lelaki bangga terhadap petai, yaitu makanan khas Indonesia. Meskipun bau yang dihasilkan sangat mengganggu, Ia tetap tidak mengurangi kecintaannya terhadap makanan ini. Ia bahkan harus berdebat dengan tokoh wanita tentang petai sebagai makanan kkas Indonesia yang harus diangkat tinggi citranya. Setelah perdebatan panjang tentang petai, tokoh lelaki dan tokoh wanita pun berpisah. Tokoh lelaki pulang ke rumah dan mencium tokoh istri. Berikut ini kutipannya.

"Kamu bau petai," kata istrinya.

"Yah, tadi memang makan petai di warung."

"Jadi kamu lagi-lagi makan petai?"

"Tidak. Cuma sekali-sekali."

"Heran, susah sekali kamu diberitahu. Kamu tidak juga insaf, kalau kamu makan petai semua orang jadi korban. Kan, tidak ada yang suka petai di rumah ini. Aku tidak, anak-anak juga tidak. Kalau kamu makan petai, semuanya jadi bau. Mulai dari WC sampai comberan di depan rumah. Baunya meruap di mana-mana. Aku, kan, malu dengan tetangga. Mereka bilang, 'idiih, orang-orang di rumah sebelah pada makan petai'. Tahanlah dirimu sedikit. Kurangi kesenangan sendiri untuk kepentingan orang 
banyak. Aku bisa mengerti, kamu sangat mencintai petai, tapi sadarilah, petai itu kumuh, sayang...." (SDCYB/2014:419-420).

Kutipan di atas menunjukkan bahwa tokoh istri tidak menyukai petai, Ia juga merasa malu dengan para tetangga yang mengomentari bau petai tersebut. Akibat yang ditimbulkan dari ketidaksukaan tokoh istri terhadap petai tersebut membuat tokoh lelaki harus makan petai secara diamdiam di luar rumah. Seringnya memakan petai di luar rumah ini membuat tokoh lelaki bertemu wanita lain yang juga menyukai petai.

\section{d. Kebutuhan Akan Kasih Sayang Tokoh dalam Kumpulan Cerpen 'Senja dan Cinta yang Berdarah" Karya Seno Gumira Ajidarma}

\section{1) Cerpen "Penari dari Kutai"}

Tokoh Barjo dan tokoh Retno sering melakukan perselingkuhan secara diam-diam. Seperti yang dilakukan saat ini, tokoh Barjo mengajak tokoh Retno untuk pergi ke pondok seberang sungai. Pertemuan antara keduanya itu dilakukan di pondok di seberang sungai. Mereka di situ untuk bermesraan, berbincang, dan melakukan hubungan seksual. Tokoh Barjo sangat perhatian kepada tokoh Retno meskipun Ia tahu bahwa tokoh Retno telah memiliki suami. Perhatian tersebut disambut oleh tokoh Retno dengan bahagia.

Hujan tiba-tiba mereda. Barjo melompat ke perahu besar itu, sebentar kemudian muncul kembali dengan bungkusan nasi putih yang hangat.

"Aduh, baik betul kamu Barjo," kata Retno yang baru saja mau menaikkan perahu.

"Ada udang dalam bungkusan itu," ujar Barjo.

"Udang? Duh, duh, baik betul kamu hari ini, ada apa jo?"

Barjo hanya tersenyum.

"Makanlah”, katanya, “aku tahu kau lapar” (SDCYB/2014:196-197).

\section{e. Tekanan Tokoh dalam Kumpulan Cerpen "Senja dan Cinta yang Berdarah" Karya Seno}

\section{Gumira Ajidarma}

\section{1) Cerpen "Suatu Ketika dalam Kehidupan Dua Orang”}

Cerita ini diawali dengan tokoh lelaki yang gelisah di malam yang telah larut. Ia tidak merasakan udara yang dingin, dadanya berdesir, dan hatinya bergidik. Ia beranjak keluar kamar dan ditegur oleh tokoh istri, tetapi Ia hanya diam saja dan mengisap rokok. Tidak berapa lama, Ia mendengar tetangganya sedang bertengkar, meskipun itu hanya berbisik-bisik, Ia tetap dapat mendengarnya.

“Tapi kenapa?!” Didengarnya bisikan itu meninggi.

"Perhiasan sudah habis, uang sekolah anak-anak belum dibayar. Mereka sudah menunggak tiga bulan, tahu? Uang belanja untuk minggu ini sudah ludes. Besok pagi kita sarapan apa?"

"Sssssttt!" 
Lantas hanya sunyi. Namun lelaki itu mendengar isak tangis. Ia sempat ikut memikirkan tetangganya itu besok mau sarapan apa. Mereka suka membeli semangkuk lontong sayur yang dimakan berlima. Istrinya juga pernah menangis seperti itu (SDCYB/2014:16-17).

Kutipan di atas menunjukkan bahwa tokoh lelaki mendengar pertengkaran tetangganya. Pembicaraan tetangganya tersebut dapat terdengar olehnya, meskipun suara tetangganya tersebut hanya berbisik-bisik. Hal ini menggambarkan bahwa Ia hidup di lingkungan yang miskin dengan rumah yang berdempet-dempetan dan rumah itu tidak terbuat dari bata, tetapi dari kayu. Seperti biasa, masalah yang dipertengkaran adalah tentang makanan, uang sekolah anak-anak yang nunggak, dan uang belanja yang telah ludes. Tokoh lelaki memikirkan hal tersebut karena pertengkaran itu pernah pula terjadi dalam rumah tangganya. Kemiskinan yang dialami oleh tetangganya tersebut persis sama seperti yang dialami dalam rumah tangganya.

\section{f. Kebutuhan Akan Kebersamaan Tokoh dalam Kumpulan Cerpen "Senja dan Cinta yang Berdarah" Karya Seno Gumira Ajidarma \\ 1) Cerpen "Cinta di atas Perahu Cadik"}

Cerita ini diawali dengan tokoh Hayati yang sedang memikul air pada bahunya sejak subuh dengan menuruni tebing sambil setengah berlari. Ia tinggal di pemukiman nelayan di pinggir laut. Tibatiba ia melihat tokoh Sukab sedang menyalakan mesin perahunya untuk mencari ikan. Kemudian, Ia pun berteriak berteriak kepadanya untuk menunggunya karena ia berniat untuk ikut. Tokoh Sukab menyuruhnya cepat untuk menyusulnya karena ia akan segera berangkat. Sampai tengah malam, perahu mereka belum juga kembali.

"Ya, kulihat perahu Sukab menyalipku dengan Hayati di atasnya. Kulihat mereka tertawa-tawa."

"Perahu Sukab menyalipku, kulihat Hayati menyuapi Sukab dengan nasi kuning dan mereka tampaknya sangat bahagia."

"Oh, ya, jadi perahu Sukab! Kulihat perahu layar kumal itu menuruti angin, mesinnya sudah mati, tetapi tidak tampak seorang pun di atasnya" (SDCYB/2014:733).

Tokoh nenek mempertanyakan keberadaan tokoh Hayati dan tokoh Sukab kepada penduduk yang bermukim di pinggir laut tersebut. Semua gubuk diketuknya satu persatu, mereka menyatakan melihat tokoh Hayati dan tokoh Sukab tertawa-tawa sangat bahagia di atas perahu cadik tersebut. Tokoh nelayan yang lainnya juga mengatakan bahwa ia juga melihat perahu tokoh Sukab, tetapi mesinnya mati dan tidak ada seseorang pun di atas perahu tersebut. 


\section{Konflik Tokoh dalam Kumpulan Cerpen "Senja dan Cinta yang Berdarah" Karya Seno Gumira Ajidarma}

\section{a. Cerpen "Suatu Ketika dalam Kehidupan Dua Orang"}

Untuk lebih jelasnya berikut ini adalah urutan sekuen yang membangun cerita tersebut.

1. Tokoh lelaki sedang gelisah dan tidak bisa tidur di rumahnya, Ia mendengar pertengkaran tetangganya

a. Pertengkaran tersebut sama dengan permasalahan di dalam rumah tangganya, yaitu faktor ekonomi.

\section{Tokoh lelaki keluar dari rumahnya dan teringat tokoh perempuan yang bukan istrinya}

a. Tokoh lelaki membaca surat dari tokoh perempuan yang juga memiliki perasaan cinta kepadanya.

\section{Tokoh perempuan bertengkar dengan tokoh suami}

a. Pertengkaran yang pertama karena tokoh suami mengejek anak-anak mereka dengan sebutan monyet.

b. Pertengkaran yang kedua karena tokoh suami menemukan surat perselingkuhan tokoh perempuan.

\section{Tokoh perempuan bertemu dengan tokoh lelaki}

a. Mereka melakukan hubungan seksual.

b. Tokoh perempuan mengakhiri hubungan perselingkuhannya dengan tokoh lelaki.

Berdasarkan analisis pembagian sekuen-sekuen tersebut, maka konflik yang terdapat pada cerpen "Suatu Ketika dalam Kehidupan Dua Orang" karya Seno Gumira Ajidarma ini terdapat pada sekuen 2,3, dan 4. Konflik internal dan konflik eksternal tersebut dapat dijabarkan sebagai berikut.

1) Tokoh perempuan dengan tokoh lelaki

Konflik eksternal yang pertama ditemukan pada sekuen 3, yaitu percekcokan antara tokoh lelaki dengan tokoh perempuan mengenai anak-anak mereka. Percekcokan ini dimulai pada pagi hari di perkampunggan tempat tinggal tokoh perempuan dan tokoh suami. Pagi itu sangat cerah karena sinar matahari masuk menyinari gang-gang kumuh dengan comberan-comberan yang berbau menyengat. Rasa panas itu sungguh-sungguh membuat gerah penduduk kampung tersebut termasuk tokoh suami.

Konflik eksternal yang kedua ditemukan pada sekuen 3, yaitu percekcokan antara tokoh suami dengan tokoh perempuan karena surat perselingkuhan yang dilakukan oleh tokoh perempuan. Setelah percekcokan tentang anak-anak mereka tersebut, konflik berlanjut dengan topik yang berbeda. Konflik itu dimulai ketika tokoh suami melihat tokoh perempuan sedang membereskan baju-baju mereka untuk 
dicuci. Ia berkata bahwa tokoh perempuan jangan bekerja yang berat-berat kerena tokoh perempuan sedang hamil besar. Seketika itu pula, tokoh suami langsung menyatakan bahwa ia menemukan surat perselingkuhan tokoh perempuan di laci rumahnya. Tokoh perempuan yang mendengar hal tersebut langsung menyalahkan dirinya sendiri karena ceroboh meletakkan surat perselingkuhannya tersebut.

2) Tokoh lelaki

Konflik internal yang pertama ditemukan pada sekuen 2, yaitu harapan-harapan yang diinginkan oleh tokoh lelaki terhadap tokoh perempuan. Konflik ini muncul ketika tokoh lelaki berjalan ke luar dari rumahnya sendirian. Ia merasakan kegelisahan, tetapi entah karena apa. Dalam perjalanannya tersebut, Ia tiba-tiba teringat kepada tokoh perempuan yang pandangan matanya adalah pandangan seorang perempuan yang berbahagia karena cinta. Sekarang langkahnya pun terhenti, Ia memikirkan harapan-harapan yang diinginkannya dari tokoh perempuan.

3) Tokoh perempuan

Konflik internal yang kedua ditemukan pada sekuen 4, yaitu kegelisahan tokoh perempuan mengenai alasannya mengakhiri hubungan perselingkuhannya dengan tokoh lelaki. Konflik ini dimulai ketika tokoh perempuan bertemu dengan tokoh lelaki. Mereka melampiaskan kerinduannya dengan melakukan hubungan seksual. Napas mereka sama-sama memburu, panas, dan bergelora. Setelah berakhir, tokoh lelaki pun menyalakan rokok dan menghembuskan asapnya ke langit-langit. Selanjutnya, Ia mengulang lagi perkataan dari tokoh perempuan yang ingin mengakhiri hubungan perselingkuhan mereka.

\section{b. Cerpen "Ia dan Jendelanya"}

Untuk lebih jelasnya berikut ini adalah urutan sekuen yang membangun cerita tersebut.

1. Tokoh Ia berada di apartemennya dan memandang orang yang sedang berlalu

a. Tokoh Ia merasakan angin yang tidak begitu kencang menerpa wajahnya.

2. Tokoh Ia menerima telepon dan seseorang tersebut menyuruhnya untuk kawin lagi

a. Tokoh Ia mengeluhkan hal tersebut berbicara dengan seseorang ditelepon.

3. Tokoh Ia kedatangan tamu, yaitu tokoh lelaki dan Ia pun berbegas mandi

a. Tokoh lelaki merupakan seorang lelaki yang telah memiliki istri.

4. Tokoh Ia selesai mandi dan berkata bahwa tokoh istri baru saja meneleponnya dan mengatakan bahwa tokoh istri bahagia hidup dengan tokoh lelaki

a. Tokoh lelaki yang mendengar hal tersebut hanya tertawa.

5. Tokoh Ia berbicara di depan cermin sambil telanjang dan berkata bahwa tubuhnya masih indah untuk lelaki yang hanya ingin membutuhkan tubuh perempuan saja

a. Tokoh lelaki membantah hal tersebut dan berkata bahwa dirinya bukan lelaki seperti itu. 
b. Tokoh Ia tidak menghiraukan perkataan dari tokoh lelaki karena baginya itu tidak penting karena Ia bisa tidur dengan siapa saja.

\section{Tokoh lelaki pulang dari apartemen tokoh Ia dan mengecup pipi tokoh Ia}

a. Tokoh Ia berkata kepada dirinya sendiri bahwa satu malam telah berlalu.

Berdasarkan analisis pembagian sekuen-sekuen tersebut, maka konflik yang terdapat pada cerpen "Ia dan Jendelanya" karya Seno Gumira Ajidarma ini terdapat pada sekuen 2 dan 5. Konflik eksternal dan konflik internal tersebut dapat dijabarkan sebagai berikut.

1) Tokoh lelaki dengan tokoh Ia

Konflik eksternal pada cerpen ini ditemukan pada sekuen 5, yaitu percekcokan antara tokoh lelaki dengan tokoh Ia mengenai tubuh tokoh Ia. Percekcokan ini dimulai ketika tokoh Ia memandang tubuhnya di cermin sambil berkata bahwa tubuhnya masih indah bagi lelaki yang hanya menginginkan tubuh dari perempuan saja. Kemudian, Ia memakain kimononya kembali.

2) Tokoh Ia

Konflik internal ditemukan pada sekuen 2, yaitu pertentangan batin antara keinginan diri tokoh Ia dengan keinginan dari orang lain. Konflik ini dimulai pada saat tokoh Ia mendapat telepon di apartemennya. Ia berbicara dengan seseorang tersebut sangat lama hingga puntung-puntung rokok memenuhi asbaknya. Tampak cahaya yang remang-remang dari ruangan tersebut, dan yang terlihat hanya bara api rokoknya yang naik turun. Ketika meletakkan gagang teleponnya Ia bergumam sendiri.

\section{SIMPULAN}

1. Alasan perselingkuhan tokoh pada sepuluh cerpen dalam kumpulan cerpen "Senja dan Cinta yang Berdarah" karya Seno Gumira Ajidarma ini, yaitu alasan keterpikatan fisik, kebutuhan biologis, kebutuhan akan komunikasi, kebutuhan akan kasih sayang, kebutuhan akan kebersamaan, dan tekanan yang menjadi landasan para tokoh dalam melakukan perselingkuhan.

2. Konflik tokoh pada sepuluh cerpen dalam kumpulan cerpen "Senja dan Cinta yang Berdarah" karya Seno Gumira Ajidarma ini terdiri dari konflik eksternal dan konflik internal yang tampak pada pembagian peristiwa melalui sekuen-sekuen. Sekuen-sekuen ini mengidentifikasi tentang bagaimana tokoh dapat terlibat konflik. Konflik internal dalam cerpen ini menyangkut tentang kegelisahan dari dalam diri tokoh. Sementara itu, konflik eksternal dalam sepuluh cerpen ini, yaitu percekcokan dan perkelahian antara tokoh. 


\section{DAFTAR RUJUKAN}

Asriana, W \& Ratnasari, Y. (2012). Kecemburuan pada Laki-Laki dan Perempuan dalam Menghadapi Perselingkuhan Pasangan melalui Media Internet, Jurnal Psikologi Vol 1, No. 1, 81-94.

Dwifatma, Andina. (2014). Antologi Cerita Pendek Seno Gumira Ajidarma di Harian Kompas 19782013. Jakarta: PT. Kompas Media Nusantara.

Faruk. (2010). Pengantar Sosiologi Sastra. Yogyakarta: Pustaka Pelajar.

Ginanjar, Soekandar, Adriana. (2009). Proses Healing pada Istri yang Mengalami Perselingkuhan Suami, Jurnal Sosial Humaniora Vol 13, No. 1, 66-76.

Hall, Stuart. (1997). Representation: Cultural Representations and Signifying Practice. London: Sage Publication.

Jannah, Devi Khaitarul. (2013). Faktor Penyebab dan Dampak Perselingkuhan Jarak Jauh (artikel), diakses 1 Juni 2015 dari http://share-all-time.blogspot.com/2014/01/faktor-penyebabterjadinya-perselingkuhan.html.

Miles, Matthew. B \& Huberman, A. Michael. (1992). Analisis Data Kualitatif Diterjemahkan oleh Tjetjep Rohendi Rohidi. Jakarta: Universitas Indonesia Press.

Minderop, Albertine. (2011). Psikologi Sastra: Karya Sastra Metode, Teori, dan Contoh Kasus. Jakarta: Yayasan Pustaka Obor Indonesia.

Nurgiyantoro, Burhan. (1995). Teori Pengkajian Fiksi. Yogyakarta: Gadjah Mada University Press.

Ratna, Nyoman, Kutha. (2004). Teori, Metode, dan Teknik Penelitian Sastra. Yogyakarta: Pustaka Pelajar.

Ratna, Nyoman, Kutha. (2010). Sastra dan Cultural Studies: Representasi Fiksi dan Fakta. Yogyakarta: Pustaka Pelajar.

Saputra, Etak. (2013). Tinjauan Yuridis tentang Perceraian Akibat Perselingkuhan (Studi di Pengadilan Agama Kota Mataram) (artikel). Diakses 25 Juni 2015 dari http://fh.unram.ac.id/wp-content/uploads/2014/05/JURNAL-ETAK-SAPUTRA.pdf.

Shaby, Ibnu. (2011). Agar Suami Tak Selingkuh!. Yogyakarta: Laksana.

Wattimena, Reza. A. A. (2010). Filsafat Perselingkuhan sampai Anorexia Kudus. Jakarta: PT. Evolitera.

Wisnuwardhani, Dian \& Mashoedi, S.F. (2012). Hubungan Interpersonal. Jakarta: Salemba Humanika. 